\title{
Which rules shape EU's external governance? \\ The patterns of rule selection in foreign and security policies
}

Esther Barbé, Oriol Costa, Anna Herranz, Michal Natorski

\begin{abstract}
This article addresses a particular aspect of EU's external governance: rule selection. Drawing on institutionalist and power-based explanations we put forward an account for the choice of the specific rules that guide policy convergence between the EU and third countries. The proposed analytical framework broadens the scope of the studies examining the externalisation of EU's rules beyond its borders, in that we claim that the EU can promote policy convergence using rules other than the EU's. More specifically, the EU also promotes policy convergence on the basis of international and bilaterallydeveloped rules. These analytical claims for explaining rule selection are checked against empirical data. We compare policy convergence between the EU and four neighbouring countries (Morocco, Ukraine, Georgia, and Russia) in three subfields within foreign and security policy: foreign policy dialogue, control of export of dual-use goods in the context of non-proliferation of weapons of mass destruction and crisis management.
\end{abstract}

Keywords: Common Foreign and Security Policy, European Security and Defence Policy, European Neighbourhood Policy, Europeanisation, External Governance. 


\section{Introduction}

The European Union (EU) has set itself the grand objective of bringing neighbouring countries “closer to the European Union in a number of priority fields" (Commission for the European Communities, 2004), thus creating a "ring of friends" with whom to share “everything but institutions" (Prodi, 2002). There is no shortage of ambition in this approach. Thus it is perhaps not surprising that a great deal of scholarly attention has been paid to what is perceived as a tendency on the part of the EU to extend some of the processes related to enlargement well beyond its territorial confines (Bauer et al. 2007; Bicchi, 2006; Kelley, 2006, Lavenex, 2004; Lavenex et al. 2008).

The usual way of depicting the relationship between the EU and its neighbours is as a harmonisation process that should lead to the adoption of EU rules by neighbouring countries. Nevertheless, we will claim that while the Union does encourage its partners to harmonise their policies with the EU in a number of fields, policy convergence can occur on the basis of rules other than EU ones. International and bilaterally-developed rules can also be at the heart of policy harmonisation. As will be argued, the selection of any of these sets of rules can be explained by combining variables drawn from the three analytical approaches outlined in the introduction to this special issue; namely, the institutionalist, power-based, and domestic factors accounts.

In order to make this point, we examine a number of issues related to the Common Foreign and Security Policy (CFSP): foreign policy dialogue, control of the export of dual-use items, and crisis management. This is an unusual choice, because the CFSP has normally not been included in the external governance approach ${ }^{1}$. Firstly, given its intergovernmental character, the CFSP would appear to lack the meso-level instruments and processes that foster external governance. However, in the second pillar 
there are Europeanisation-like dynamics that go well beyond the mere sum of national policies, or their least common denominator (Smith, 2004). Some of these processes are nearly as old as European foreign policy. The term of 'Brusselisation' (Allen, 1998) has been used to denote that "while the relevant competences do remain ultimately at the disposal of the Member States, the formulation and implementation of policy [is] increasingly Europeanized and Brusselized by functionaries and services housed permanently at Brussels” (Müller-Brandeck-Bocquet, 2002: 261). Besides, the fact that Community resources are needed to develop the CFSP has fostered cross-pillarisation (Stetter, 2007). Secondly, the CFSP is itself a foreign policy and so would seem to fit uncomfortably with an analytical framework that stresses the external projection of internal arrangements. The rest of this paper will address this claim and argue that the CFSP can be interpreted perfectly well through the lenses of external governance, especially if EU, international, and bilateral rules are included in the analysis.

The remainder of the article is organized as follows. Section 2 presents (i) a conceptualisation of our dependent variable, rule selection for policy convergence, and (ii) the independent variables and how they relate to the analytical approaches set out in the introductory chapter to this special issue. Section 3 examines three subfields within the issue area of foreign and security policy (foreign policy dialogue, control of the export of dual-use items, and crisis management) in four neighbouring countries (Georgia, Morocco, Russia, and Ukraine). Section 4 summarizes our findings and presents conclusions about the external governance approach in the domain of foreign and security policies. 


\section{Conceptualizing rule selection}

As argued, we want to account for the patterns of rule selection for policy convergence. In other words, we are interested in explaining the choice of specific rules as the basis to increase the "similarity between one or more characteristics of a certain policy" in the EU and neighbouring countries (Knill, 2005: 768).

Two aspects of this approach need to be stressed. First, we talk of policy convergence rather than of the transfer of policies or rules. This is because we think that the notion of policy convergence can better capture the fact that the increasing similarity in policy across different actors might be the result of a more complex interaction than the one-way process that is suggested by the notion of transfer. We see rule selection as the product of the interaction between the EU and third-party countries, either by explicit agreement between both parties or by anticipation on the part of the EU (because the continuous interaction between the EU and its neighbours provides the Union with input on how the latter might regard the possibility of adopting different processes to achieve policy convergence). In sum, either directly or indirectly, neighbouring countries play a critical role in determining which externally promoted rules may be adopted and how.

Second, we claim that the relationship between the EU and its neighbours can be based on rules other than the EU's. While sometimes, the EU creates the standards that it exports (Björkdhal, 2005; Lavenex and Uçarer, 2004), at other times the policy standards originate elsewhere. In this latter case, the EU and the third actor may work together to set a tailor-made rule, or the EU may act more as a taker/transmitter of rules that have been elaborated in other international fora. 
Given the above, the EU and its neighbours can pursue policy convergence in three different ways. (i) They may work towards convergence to EU rules, in which case the neighbouring partner will adopt, in part or in full, the acquis communautaire. specific aspects of the EU acquis politique, or well-codified rules of a constitutive character that are related to human, social, and economic rights as laid down by the EU. (ii) They may work towards convergence to international rules, in which case a neighbouring partner will adopt acknowledged international standards as a result of EU facilitation or encouragement. (iii) The EU and neighbouring countries can pursue convergence by developing rules bilaterally.

The question naturally arises of whether there is any pattern behind the selection of EU, international, or bilateral rules as the basis for policy convergence. As presented in the introduction to this special issue, explanations of the effectiveness of external governance can be grouped as follows: (i) the institutionalist account, structured around the degree of legalisation and legitimacy of the EU's rules; (ii) the power-based explanation, which focuses on the EU's bargaining power; and (iii) the domestic factors approach, whose core aspects are the administrative capacity of the target state, the costs of adoption, and veto players, as well as the domestic resonance of EU-promoted rules. For the purpose of our analysis, and given our conceptualisation of the selection of rules for policy convergence, we need to organise the independent variables in a slightly different way. The notion of policy convergence (and its emphasis on the agency of neighbouring countries) requires an understanding of the variables that takes into account their relational and intersubjective character. It requires treating the domestic conditions of the target state as an integral part of the legitimacy of EUpromoted rules (and EU efforts to promote rules), and of the EU's bargaining power visà-vis neighbouring states. Thus, we identify two independent variables that broadly 
coincide with the institutionalist and power-based approaches, while integrating the account that is based on domestic factors.

The first variable, mutual perceptions of legitimacy, stems from the institutionalist account and combines both legalisation and legitimacy concerns. The legalisation bit is most relevant for the transfer of EU rules. Their chances of becoming the standard of policy convergence hinges on the way and the degree to which they are encapsulated in legal statutes. As hypothesized in the introduction to this special issue, "the more that EU rules are legalised, the more likely they will be selected, adopted, and implemented beyond EU borders” (Lavenex and Schimmelfennig, 2009). In addition, this variable is based on the premiss that actors adopt new rules when they are convinced of their appropriateness (Lavenex and Schimmelfennig, 2009). In other words, given our conceptualisation of policy convergence, we take very much into account the intersubjective character of legitimacy. The resonance between the rules that can shape policy convergence and the normative context in the neighbouring country is thus of critical importance. Finally, perceptions of legitimacy also concern how far the potential adopter of external rules can identify with the actor promoting them and the legitimacy attributed by the third state to the process by which standards for convergence are set.

Legitimacy is hard to measure as decision-makers in neighbouring countries do not usually address this aspect in public. It is all too easy to resort to the observation of preferences, but then the risk is high of conflating independent and dependent variables. In this paper we measure legitimacy by looking at the behaviour of the third party as conducted independently from the interaction with the EU. More specifically, we identify instances of behaviour that are previous to attempts by the EU to foster policy convergence or that take place either in relation to similar topics or in different settings. 
The second variable, EU bargaining power, stems from the power-based account. The arguments for adopting this variable are quite straightforward: (1) states decide to accommodate externally defined rules by comparing the costs and benefits of different courses of action, and (2) the EU may alter the cost-benefit assessment through incentives and disincentives (if it has enough bargaining power vis-à-vis the neighbouring states). Both the costs and benefits of adopting particular rules depend partially on the administrative capacity of target states. There is a further point to be made here. Neighbouring countries’ cost-benefit analyses are likely to include both substantive and process-related considerations. In other words, neighbouring states can be expected to take into account not only the costs and benefits of adopting particular rules per se, but also the effects that any course of action might have on their relationship with the EU. There are two reasons for thinking that the latter can play a particularly relevant role when it comes to the CFSP. First, in the area of foreign policy, actor networks are usually less densely populated; hence, policy convergence is less likely to undermine the interests of veto players that might want to hinder the adoption of rules. Second, foreign policy is a highly visible and relatively unambiguous way of signalling the will to cooperate more closely with the EU.

We claim that change in these two variables explains the selection of rule for policy convergence. From an analytical standpoint, convergence on the basis of EU's rules appears to be the most demanding option, because the EU's rules are normally more detailed and context-bound than international or bilaterally-developed rules; hence, the costs related to their adoption and the probability that they are seen as intrusive or patronizing by the third-party state will also be higher. Consequently, we expect convergence to be based on the EU's rules only when the two variables have a positive value, i.e. if the EU is able to provide substantial incentives and the rules at 
issue are perceived as legitimate. When either the legitimacy of the EU's rules or the EU's bargaining power is insufficient, we expect policy convergence to be based on other kinds of rule. More specifically, when the EU's rules are not deemed legitimate, or less legitimate than international alternative rules, we expect international rules to take central stage with respect to policy convergence. Alternatively, if the EU's bargaining power is insufficient, in that the neighbouring state is both uninterested in adopting external rules and powerful enough as to resist EU pressures in the particular issue area at hand, we expect policy convergence to be based on bilaterally-developed rules.

Having presented our analytical claims for explaining rule selection in EU's external governance, we turn in the following section to whether or not the claims are borne out by empirical data. We compare policy convergence between the EU and four neighbouring countries (Morocco, Ukraine, Georgia, and Russia) in three subfields within foreign and security policy. Our analysis proceeds in two steps. In the first step, we identify, on the basis of basic bilateral documents, the rules that govern policy convergence in each case. In the cases of Ukraine, Morocco, and Georgia we look at ENP Action Plans, while in the case of Russia we review the document that established the Four Common Spaces and the Partnership and Cooperation Agreement. In the second step, we assess the variables mutual perceptions of legitimacy and EU bargaining power in each case in order to confirm or disconfirm our claims about the patterns of rule selection. The analysis of these variables draws mainly on a closer examination of official documents from the Council and the minutes of relevant bilateral meetings. The results of the case studies are summarised in Table 1 at the end of the next section. 


\section{External governance meets foreign and security policies}

\subsection{Foreign Policy Dialogue}

CFSP acts are the clearest expression of the EU acquis politique in the field of foreign policy. Most CFSP acts, especially CFSP Declarations and Statements, have an informational and declaratory character, indicating the stance of EU member states on particular topics of the international agenda. In addition, there are two legally binding CFSP acts: Common Positions and Joint Actions. The former are usually adopted in order to define the EU approach to a particular matter of a geographical or thematic nature, and are frequently employed to impose restrictive measures on third actors. The latter have an operational character and put in place EU diplomatic activities and missions.

In the subarea of foreign policy dialogue we define EU-based convergence as the regular alignment by a third country with the positions expressed by the EU in the CFSP acts. The cases of Ukraine and Georgia fall under this EU-based option. The process of alignment with CFSP acts began in June 2005 for Ukraine and Moldova, and in June 2007 for Georgia, Azerbaijan, and Armenia. The process followed the mechanisms that were already in place for countries that have a recognised EU accession perspective, including European Free Trade Association (EFTA) countries. Conversely, in the case of Russia, convergence is sought through international rules, because the main objective is the "strengthening of the international order based on effective multilateralism” (Council of the European Union, 2005a: 33). Finally, in the case of Morocco, the EU agreed that the dominant element of convergence should be bilaterally-developed rules, “allowing [both parts’] positions and reciprocal interests to 
be taken into account” (Association between the European Union and Morocco. The Association Council, 2005: 8).

That Ukraine and Georgia adopted an EU-based process of convergence on rule selection may be explained by the EU's bargaining power being strong and mutual perceptions of legitimacy being positive. From the perspective of the EU, enlarging the community of countries that support the CFSP through a structural mechanism of alignment with it is another step in strengthening its international influence and a visible further step towards implementing the European Neighbourhood Policy. From the perspective of the third countries, their alignment with CFSP acts is mostly a declarative act of political commitment, although in some cases it can imply political costs in one of the most sensitive areas of state sovereignty; namely, foreign policy. Particularly with respect to CFSP Declarations, alignment has often taken place in relation to areas regarding which Ukraine and Georgia do not have a well-established policy, and where the cost of implementation is not high. In the case of Ukraine, for example, the changes consisted mainly in setting up a coordination mechanism between the Ukraine's representation in Brussels and the Ministry of Foreign Affairs in Kiev. However, potential costs increase when it comes to Common Positions, which can include sanctions or other restrictive measures against particular countries, individuals, or groups of people. Indeed, between 2005 and 2007, both Ukraine and Georgia refused to align with EU Common Positions on several occasions, due to their costly implications 2. The existence of a permanent procedure for foreign policy consultations puts considerable political pressure on the third state, because the degree of alignment is taken into account in the review of the implementation of the ENP Action Plan and is considered to indicate the extent of overall political cooperation with the EU. But all things considered, the potential costs of alignment are offset by expectations of 
intensified political relations with the EU, a goal that both Ukraine and Georgia pursue due to their ambitions regarding accession.

An analysis of EU-Ukraine and EU-Georgia relations since 2000 also reveals that perceptions of legitimacy were also positive. The predisposition of Ukraine to EUbased convergence in foreign policy dialogue was already apparent in 2000, when it began to align itself with EU statements and declarations on a unilateral basis ${ }^{3}$. Along the same lines, the possibility of aligning with CFSP acts was celebrated in Georgia as "an important dividend for the country whose pro-Western leadership has claimed to pursue the same goals in foreign policy and prescribe to the same values that the European Union shares” (The Georgian Times, 2007). The institutionalisation of the mechanisms of convergence towards EU rules was also made more likely by previous positive experiences of consultation and cooperation at working party level (Council of the European Union, 2001: 5).

As for Russia, the process of convergence is anchored in international rules. This is mainly explained by the legitimacy that Russia attributes to international law in its self-perception as a global player. Indeed, Russia presents herself as a firm defender of international law, on the basis of the statutes of the United Nations Charter and the Helsinki Final Act. Closer cooperation with the EU in CFSP matters has to date been welcome by Russia, but this takes place on the basis of international rules, which she regards as a means of "overturning the present order, undermining the 'unipolar trend' and changing the distribution of power in the international system in favour of Russia” (Splidsboel-Hansen, 2002: 448). Cooperation with the EU is therefore part of Russia's overall strategy in foreign policy to counterbalance the perceived unipolar structure of the international system and to detach the United States from the European security system. The selection of issues dealt with in EU-Russia common statements and 
declarations on matters, such as the Middle East conflict, terrorism, or the cooperation on political and security matters in Europe, illustrates this point.

In the case of Morocco, convergence is based on bilateral rules, despite EU's efforts on a more EU-tailored process. Indeed, since 2005 relations between the EU and Morocco in terms of foreign policy dialogue have been strengthened to a point where discussions have already begun on the possibility of setting up a mechanism to allow for Morocco's alignment with CFSP acts, but as of the time of writing, no agreement has yet been reached (Commission for the European Communities, 2008). Foreign policy consultations are still conducted in the framework of a "reinforced political dialogue" at the level of the Troika, the Political and Security Committee, and even between policy planning services. This bilateral setting is supplemented by the multilateral dimension of the Barcelona Process. Similarly, the measures envisaged within "advanced status" for Morocco in the foreign and security field stress that measures should be implemented to strengthen cooperation, but only on a case-by-case basis and with no structured, far-reaching framework. In addition, the proposals are silent about the normative content of any potential convergence in this field (EU-Morocco Association Council, 2008: 2).

Both the absence of incentives and legitimacy explain Morocco’s reluctance to establishing mechanisms for aligning with CFSP acts. The EU's lack of legitimacy appears to be the crucial factor in the sense that Morocco's foreign policy stances diverge substantially from that of the EU. This is reflected by, for example, the voting behaviour of Morocco at the General Assembly of the United Nations, which is considerably at odds with that of the EU ${ }^{4}$. Topics on the UN agenda that recurrently separate the EU and Morocco relate to the Middle East, Maghreb, and especially the Western Sahara, human rights, and democratisation. Given these fundamental 
divergences, the potential costs of setting up a mechanism of alignment with CFSP acts would be much higher for Morocco than in the other cases, but also for the EU, as a high rate of non-alignment would visualise EU's lack of support from one of its closest partner countries in the Mediterranean. In view of that, the EU has opted in its relations with Morocco for a process of bilaterally-based convergence, where forms and institutions dominate over the substance of the relationship.

\subsection{Control of the export of dual-use items in the context of non-proliferation of WMDs}

Given that certain goods, technologies, and services have a dual use, in that they can be used both for peaceful purposes and to build weaponry, the EU has begun to establish an internal scheme to control the export of these items within and beyond the EU (Schmitt, 2000). In 2000, a new system for controlling the export of dual-use items was set up that framed the issue as a trade-related one and was based on a European Community Regulation (Council of the European Union, 2000a). Since 2003, policies in this domain have been considered as part of the wider EU strategy against the proliferation of weapons of mass destruction (WMD) that has been adopted within the CFSP mechanisms (Council of the European Union, 2003). This strategy emphasizes the need for a more multilateral approach to combating the proliferation of weapons of mass destruction.

Given this security and universalistic approach to the matter, EU's more trade oriented Regulation might be deemed as inappropriate as a basis for policy convergence. The EU Regulation concerning export controls of duals use items focuses on their economic aspects and on the liberalization of intra-Community trade, where "controls must be proportionate to the risk and must not distort the Single Market or 
damage the global competitiveness of European enterprises" (Council of the European Union, 2006: 2). Additionally, the EU export-control system is based on the principles of mutual confidence and mutual recognition of decisions of national export controls authorities, which cannot always hold in the relationships with third countries.

Therefore, the basis for policy convergence with neighbouring countries is essentially the United Nations Security Council Resolution 1540, adopted in 2004. This legally binding Resolution exhorts states to refrain from supporting by any means nonstate actors from developing, acquiring, or using WMD. The resolution also imposes a general obligation on all states to establish domestic controls to prevent the proliferation of WMD and their means of delivery, including controls covering related materials (i.e. dual-use goods). In the post-11-September era, this resolution constituted one of the most visible results of global efforts aimed at combating proliferation of Weapons of Mass Destructions. Therefore, it is widely perceived as a legitimate basis for action by a very large number of UN member states, including Georgia, Russia, Morocco, and Ukraine, as shown by the degree of compliance with procedural commitments ${ }^{5}$. At the same time, the UN Resolution fits well with the policy objectives and multilateral approach of the EU strategy, which had already anticipated some of the elements of UNSCR 1540 (Matiussi, 2007) and intends to build up universal mechanisms of nonproliferation (Council of the European Union, 2003). Besides, both documents frame export controls aimed at combating proliferation of weapons of mass destruction as a security issue (as opposed to a commercial one). In sum, the EU has generally preferred basing policy convergence on international rules, instead of promoting its own intra-EU policies. Nevertheless, these international rules are supplemented with bilateral ones in the case of Russia and with EU ones in the case of Ukraine. These differences are also 
consistent with our explanation of the factors at stake during the process of rule selection.

As said, Russia is a special case when it comes to non-proliferation efforts. The EU-Russia Road Map combines the reference to international rules with the will to develop them further bilaterally. Thus, both parties pledged to foster the "universal adherence to and greater effectiveness of the relevant international instruments" and the “enhancement and, where relevant, enlargement of export control regimes”. At the same time, they agreed to set up a "dialogue on non-proliferation, disarmament and arms control, including regional aspects, for further convergence of positions and possible cooperation of activities within existing international mechanisms”. In other words, the EU and Russia are willing to promote their common positions in other international fora in order to reinforce international regimes. For example, in 2004, the EU's members of the UN Security Council (France, the United Kingdom, Romania, and Spain) together with Russia, the United States, and the Philippines, presented the project of Resolution 1540. This mixed pattern of convergence along international and bilateral rules has to do, first, with Russia's leverage on this issue. Russia plays a fundamental role in international non-proliferation efforts. As evidenced by the EU-Russia Outreach Project, the EU is highly interested in harmonizing rules in this domain in order to facilitate trade in dual-use items with this country ${ }^{6}$. Secondly, it reflects Russia's consideration that only international regimes can provide sufficient guarantees regarding the efficient control of the circulation of dual-use items. Consequently, Russia’s willingness to engage with EU in the export control of dual-use goods rests to a large extent on the legitimacy attributed to the implementation of international rules and on the fact that cooperation shows due regard for the special condition of Russia as a large, important country seeking international reinforcement of its status. 
In comparison with EU-Russian cooperation, the ENP Action Plan with Ukraine portrays a more typically EU-driven approach to policy convergence. There is a common commitment to "the accession to and implementation of relevant international instruments and export control regimes, in the light of the EU WMD Strategy adopted by the European Council in December 2003 and the GAERC conclusions of 17 November 2003" (Partnership between the European Union and Ukraine. The Cooperation Council, 2005: 12, emphasis added). Such EU-based convergence is, however, perhaps not surprising if it is seen in the context of other areas of EU-Ukraine cooperation regarding the CFSP and ESDP. As noted above with respect to dialogue on foreign policy, Ukraine is very interested in maintaining a good relationship with the EU in the hope that this can foster further rapprochement with, or even integration into, the Union. The views expressed by Ukrainian officials lend support to the idea that Ukraine accepts EU demands as legitimate and that EU legislative and administrative templates are welcome as models (Checheyuk, 2008). However, independently from perspectives on prospective membership of the EU, there are also other incentives. As recognized in a report that compares Ukrainian and EU legislation in the field of export controls, "the wish for close economic and trade related ties with the EU is in itself a strong incentive for alignment and harmonisation of trade procedures with that of the EU” (Scientific and Technical Center, 2008). Finally, Ukraine does not attempt to exert a decisive influence on international rules regarding the spread of dual-use items. However, she demonstrates full compliance with them in order to deflect accusations of facilitating the spread of dangerous items and has a long record of defending stances that are fairly consistent with those of EU member states.

In the cases of Georgia and Morocco, the interest in the control of the export of dual-use items is less pronounced, given that both countries' capabilities with respect to 
WMD are considerably less than those of Russia and Ukraine. As a result, policy convergence has been structured only around general provisions that may be derived from international rules, since such provisions may constitute a normatively neutral ground (thereby providing a cloak of legitimacy) for cooperation. Consequently, the bilateral documents agreed with Georgia and Morocco include similar provisions about establishing (Morocco) or developing (Georgia) an effective system for national export controls that will cover the export and transit of WMD-related goods, including the control of the end use of dual-use technologies with respect to their potential to be used in WMDs, as well as effective sanctions for breaches of export controls, using UN Resolution 1540 as a basis. Morocco was also invited to participate in the EU Outreach Project, but the scope of the cooperation within this project is much narrower than that with Russia and Ukraine.

\subsection{Crisis management operations}

Crisis management operations are the clearest expression of the European Security and Defence Policy (ESDP). The EU foresaw from the very outset the possibility of receiving contributions to its crisis management operations from third-party countries, and at the time of writing more than 20 third-party states have contributed personnel and assets to ESDP missions, 11 of which have become Member States of the EU. Yet, there are different modalities and degrees of participation.

We define EU-based convergence in the domain of crisis management as the existence of structural mechanisms for the third country's involvement in the ESDP, such as the signature of framework participation agreements or agreements to regulate the exchange of classified information. This is the case with respect to the EU's 
relations with Ukraine. Convergence on the basis of bilateral rules ranges from cases of ad hoc participation of third-party countries in ESDP missions through specific participation agreements to less developed schemes of cooperation that cover the conducting of regular dialogues on security and defence issues. Bilaterally-based convergence is the dominant trend in the EU's relations with Morocco, Russia, and Georgia. Finally, convergence on the basis of international rules is also a theoretically possible option. This would be the case if the EU were found to be a major actor that encouraged neighbouring states to further cooperate in the crisis management activities of other international institutions, such as the UN, the Organisation for Security and Cooperation in Europe (OSCE), or the African Union. However, this has not been observed in practice.

In the case of Ukraine, the ENP Action Plan established the aim of further institutionalisation of relations in the field of ESDP by concluding (a) an agreement that establishes a framework for the participation of Ukraine in EU crisis management operations, and (b) an agreement on security procedures for the exchange of classified information. Both agreements, concluded in July 2005, confirmed the parties’ will to go beyond the ad hoc procedures that had regulated Ukraine's previous involvement in ESDP missions (Sari, 2008: 60-61). Their significance is shown by the fact that the EU has concluded similar arrangements only with candidate and/or associated countries and/or NATO members.

Ukraine's willingness to become more involved in ESDP activities and structures is motivated by a similar confluence of factors, as in the case of foreign policy dialogue: low costs, compared to possible high rewards derived from showing a capacity to participate in important dimensions of European integration, and high legitimacy attributed to EU's security and defence policies. In addition, participation in 
ESDP is deemed to enhance the international credibility of Ukraine as a security provider in Europe, an important element in the country's push to become a member of NATO. More to the point, since 1999, Ukraine has expressed her willingness to cooperate in this field and as early as 2000, the country presented various far-reaching proposals to enhance cooperation in the CFSP/ESDP domain (Council of the European Union, 2000b).

As for Morocco, the Action Plan establishes the possibility of participating in EU-led civil and military peacekeeping exercises and operations. The aim of strengthening dialogue and cooperation in ESDP matters is also amply covered, e.g. participation in training and activities related to the prevention of conflict, and the management of crises and natural disasters or civil protection. However, the process of convergence is mostly to be developed on a bilateral basis, without a clear EU or international normative template. Morocco constitutes a special partner for the EU, because it is the only southern Mediterranean country that has contributed to an ESDP operation, the EUFOR 'Althea' in Bosnia and Herzegovina. However, it should be noted that this participation was agreed on ad hoc basis and the EU's endeavours to “organise our ESDP relations in a more structured way" have not yet succeeded (Commission of the European Communities, 2008). The possibility mentioned by the EU of signing a framework participation agreement on ESDP operations and one on the exchange of classified information has not yet been realized.

Morocco’s preference for a bilaterally-based scheme can be explained by factors pertaining to the bargaining power model, although concerns about legitimacy point in the same direction. Regarding incentives, Morocco’s selective participation in an ESDP missions is more related to process-oriented than substantive considerations. In other words, this involvement serves Morocco’s interest in distinguishing herself from other 
Mediterranean countries in her attempt to negotiate an "advanced status" under the ENP. However, the EU's bargaining power with respect to Morocco in the specific domain of security and defence is low. Cooperation with the EU in this field does not offer a significant added value in comparison to other frameworks of cooperation in military affairs such as NATO Mediterranean Dialogue, which has gained ever more significance, especially since the launch of the Istanbul Cooperation Initiative in 2004. Morocco has been indeed one of the most cooperative partners in the Mediterranean Dialogue, taking part in many of its training and modernisation programs and even in NATO led missions, such as the KFOR (Benavides Orgaz, 2007: 23-29). With respect to legitimacy, an important element in Mediterranean countries' reluctance to participate in the ESDP is that most of the missions are not sanctioned by a clear mandate from the UN. In addition, differences in the political assessment of certain crisis and criticisms towards asymmetrical designs for cooperation have remained common in the Mediterranean countries (Boguslawska, 2008: 4). In fact, the development of the ESDP was always regarded with distrust by southern Mediterranean countries in general (Balfour, 2004: 15).

The Road Map with Russia establishes a bilateral background for convergence, "through mutual result-oriented cooperation, including through elaboration of possible joint initiatives in support of efforts in agreed formats as well as by relevant international organizations and structures, in particular the UN and the OSCE” (Council of the European Union, 2005a: 34). The EU has attempted to improve the conditions for Russian involvement in ESDP operations (set by the EU in Seville 2002) and to create networks with Russia to increase cooperation in the field of crisis management (Webber, 2001). However, Russia has shown little interest in more structured cooperation, by, for example, refraining from establishing a framework participation 
agreement that had been suggested by the Council of the European Union in 2004 (Sari, 2008). The only formalised involvement of Russia in ESDP missions so far is the ad hoc participation agreement in EUFOR Chad/CAR operation, concluded on the 18 November 2008.

Similar to the case of Morocco, Russia's reluctance to establish more EU-based convergence paths is explained by the EU's limited bargaining power and factors pertaining to legitimacy. Russia's veto power in the UN Security Council makes its involvement crucial for a number of crisis management operations. Involvement in the ESDP does not bring any added value for Russia either. From the EU's standpoint, the lack of progress in cooperation has often been attributed to a lack of a good understanding of how the EU works, in particular in the field of CFSP and ESDP (Council of the European Union, 2005b). However, Russia has pointed to the lack of credibility of the ESDP, ever more willing to focus on relations with NATO as the only effective counterpart (Gomart, 2008: 14). On the other hand, Russia has expressed her opposition to ESDP operations in regions adjacent to EU and Russian borders. In this sense, Russia is keen on emphasising the role of regional organisations, such as the OSCE, in crisis management.

Finally, in the case of Georgia, cooperation is to be based on bilaterallydeveloped rules, but there are in fact no clear-cut demands for convergence. The Action Plan foresees only an enhanced political dialogue and regular exchange of information on the CFSP, including ESDP. There are also general provisions about closer cooperation, particularly regarding regional stability and crisis management. In fact, the bilateral agenda is far more focused on the priority of tackling the frozen conflicts in South Ossetia and Abkhazia. Therefore, the Action Plan includes a whole section devoted to the different measures aimed at cooperation in the settlement of the conflict 
in Georgia (Partnership between the European Union and Georgia. The Co-operation Council, 2006). In any case, there are factors that explain why convergence is not envisaged on the basis of the EU's rules, as is the case with foreign policy dialogue. Most importantly, the EU's interest in Georgia's contribution to ESDP operations is very low, given Georgia's meagre record of participation in international crisis management operations. To date, Georgia has deployed troops within the US-led military mission in Iraq and contributed briefly to the International Security Assistance Force (ISAF) in Afghanistan. Georgia also participated in the NATO-led Kosovo Force (KFOR) in Kosovo, but withdrew its contribution in early 2008, after Kosovo declared independence. The decision to withdraw from this NATO operation can shed some light regarding Georgia's perceived legitimacy of the ESDP. On the one hand, Georgia is willing to integrate in Euro-Atlantic structures of security and defence, as is stated clearly in the Georgian security strategy document 2006-2009 ${ }^{7}$. On the other hand, divergence of positions between EU's and Georgia’s political approach to conflict resolution in the region, such as in the case of Kosovo, might be a source of future disagreement.

Table 1. Summary of the results

\begin{tabular}{|c|c|c|c|c|c|c|c|c|}
\hline COUNTRIES & \multicolumn{2}{|c|}{ Georgia } & \multicolumn{2}{|c|}{ Morocco } & \multicolumn{2}{|c|}{ Russia } & \multicolumn{2}{|c|}{ Ukraine } \\
\hline ISSUE AREAS & $I V$ & $D V$ & $I V$ & $\overline{D V}$ & $I V$ & $D V$ & $I V$ & $D V$ \\
\hline Foreign Policy & $\begin{array}{l}\text { P: }+ \\
\mathbf{L}:+\end{array}$ & $\mathrm{EU}$ & $\begin{array}{l}\text { P: - } \\
\text { L: - }\end{array}$ & BIL & $\begin{array}{l}\text { P: }+/- \\
\text { L: - }\end{array}$ & INT & $\begin{array}{l}\text { P: }+ \\
\text { L: }+\end{array}$ & $\mathrm{EU}$ \\
\hline $\begin{array}{l}\text { Export control } \\
\text { of dual-use items }\end{array}$ & $\begin{array}{l}\text { P: }-/+ \\
\text { L: }-\end{array}$ & INT & $\begin{array}{l}\text { P: }-/+ \\
\text { L: }-\end{array}$ & INT & $\begin{array}{l}\text { P: - } \\
\text { L: - }\end{array}$ & INT/BIL & $\begin{array}{l}\text { P: }+ \\
\text { L: }+\end{array}$ & INT/EU \\
\hline $\begin{array}{l}\text { Crisis } \\
\text { management }\end{array}$ & $\begin{array}{l}\mathbf{P}:- \\
\mathbf{L}:+/-\end{array}$ & BIL & $\begin{array}{l}\text { P: - } \\
\text { L: - }\end{array}$ & BIL & $\begin{array}{l}\text { P: - } \\
\text { L: - }\end{array}$ & BIL & $\begin{array}{l}\text { P: }+ \\
\text { L: }+\end{array}$ & $\mathrm{EU}$ \\
\hline
\end{tabular}

Independent variables (IV): EU's bargaining power (P); Perception of legitimacy of EU's rules (L). Dependent variables (DV): converge towards EU's rules (EU); convergence towards international rules (INT); convergence towards bilaterally-developed rules (BIL). 


\section{Conclusions}

EU policy towards its neighbourhood area has increasingly been analysed in terms of the process by which the EU responds to external challenges by attempting to expand its own system of governance beyond its member states. In the above discussion, we have broadened the scope of the debate by arguing that the EU can promote policy convergence, rather than the unilateral transfer of rules, using rules other than the EU's. More specifically, the EU promotes policy convergence on the basis of international and bilaterally-developed rules.

Each kind of policy convergence corresponds roughly to one third of the case studies, though there are instances of combined rules. This fits the idea proposed at the beginning of the article that the conditions that make convergence based on EU rules possible (in terms of incentives and legitimacy) are not all-pervasive. It is also interesting that Ukraine (where the EU's incentives and legitimacy score high) is the neighbouring country in three out of four of the cases of EU-based convergence. Here, the overarching disposition to further integrate with the EU underlines the relevance of process-related considerations. Conversely, when EU rules are perceived as less legitimate than international ones, the latter are selected as the foundation for convergence. For example, though Russia is interested in cooperating with the EU in foreign policy field to foster multipolarity, it denies the EU authority to act as a rule maker in this domain. International-based convergence is also prevalent in the control of the export of dual-use items, despite the fact that measures for control are strongly legalised in the EU as part of the first pillar, because EU rules themselves are embedded in an international regime that is widely perceived as legitimate. Finally, when the EU does not have the incentives or bargaining power to promote its own rules, bilateral rules are developed. Normally, the setting of bilateral rules for convergence is related to 
the lack of bargaining power on the part of the EU, as in the case of cooperation with Russia and Morocco in crisis management, but the EU can also be uninterested in offering stable schemes to neighbours, as with Georgia on this same issue. Sometimes, there is little mutual perception of legitimacy and little bargaining power. In this case, rules can be selected by any of the available courses of action and this selection needs to be assessed on a case-by-case basis. However, the empirical evidence suggests that mixed solutions can be expected that combine bilateral and international rules.

Table 1 shows the presence of some interesting patterns, both sector- and country-driven. For instance, Russia and Morocco are less prone to participate in EUcentred policy convergence (with no instances in our case studies). In addition, with respect to the control of the export of dual-use items, convergence seems to be based on international rules (sometimes combined with other rules). We think that the systematic replication of this approach in a broader range of areas would allow the emergence of a more complete account of the EU as a regional actor and the patterns of inclusion/exclusion that it is promoting.

Our cases do not allow us to take a stance in favour of any of the analytical approaches presented in the introduction to this special issue. Precisely, none of the central variables used in the analytical approaches is individually sufficient to account for the selection of rules for policy convergence in the CFSP; however, they all seem to be necessary. For example, institutionalist accounts do not explain why a powerless EU cannot promote convergence on the basis of strongly legalised and well legitimized EU rules. Similarly, the power-based approach cannot explain why bargaining power is not sufficient for EU-based convergence to take place when international rules are perceived as more legitimate than EU ones. In addition, if policy convergence and rule selection are processes in which both the EU and neighbouring parties play an active 
role, material and ideational factors need to be defined in a relational way, thus including the neighbours' domestic factors. Finally, the empirical evidence seems to suggest the existence of a certain correlation of power and legitimacy that is worth paying attention to in further researches.

To conclude, we have found no empirical reason to maintain the tendency to exclude CFSP issues from analyses of external governance. In this area, the EU is far from being a traditional foreign policy actor. On the contrary, the EU has the explicit will to promote policy convergence (whatever the normative foundation of this process might be) and to expand the regulatory and (sometimes) the organisational boundaries of the EU. This is precisely as the literature on external governance would have it.

\section{Biographical notes}

Esther Barbé (Esther.Barbe@uab.cat) is Professor of International Relations at the Autonomous University of Barcelona and and Program Coordinator at Institut Barcelona d'Estudis Internacionals. Oriol Costa (Oriol.Costa@uab.cat) is Lecturer of International Relations at the Autonomous University of Barcelona (on a leave) and post-doctoral researcher at the Centre for European Integration (Otto-Suhr-Institut for Political Science) of the Freie Universität Berlin. Address: Faculty of Political Sciences and Sociology. Anna Herranz Surrallés (Anna.Herranz@uab.cat) is Research Fellow at the Observatory of European Foreign Policy of the Institut Universitari d'Estudis Europeus. Michal Natorski (Michal.Natorski@uab.cat) is Affiliated Lecturer of International Relations at the Autonomous University of Barcelona. Address: Faculty of Political Sciences and Sociology. 


\section{Address for correspondence}

Esther Barbé - Institut Barcelona d'Estudis Internacionals. Elisabets 10, 08001 Barcelona, Spain.

\section{Acknowledgements}

The authors are indebted to Frank Schimmelfennig and Sandra Lavenex, for their helpful comments on earlier versions of this article. The authors would also like to thank the participants of the workshop on "EU's external governance" held at the University of Luzern on the 13 September 2008 as well as three anonymous referees. This article has also benefited from the research carried out within the project EUPROX -“Europeanisation, Internationalisation and Coordination in the Proximity of the European Union"-, funded by the R+D National Plan of the Spanish Ministry of Education and Science (SEJ2006-03134/CPOL).

\section{Notes}

1. For a governance approach to the studies of the EU's security policy see Kirchner (2006); and specifically for the EU's relations with the neighbourhood in the area of foreign and security policies, see Barbé (2008) and Smith and Weber (2007).

2. The reasons for this in the case of Ukraine had to do with the high costs for “Ukrainian national interests” of EU stances on topics such as energy security (Uzbekistan), border management and the management of the Chernobyl disaster (Belarus), the peace-settlement process (Transnistria), arms trading (Burma), and general principles of foreign policy (Georgia). Interviews with Ukrainian diplomats, Brussels, 29 March 2007. 
3. Interviews with Ukrainian diplomats, Brussels, 29 March 2007.

4. Morocco, as an active member of Group 77, voted differently from the EU unified positions in 24 out of 52 instances during the 58th session of the UN General Assembly (2003-2004) In comparison, Ukraine voted differently in nine cases and Georgia four 4 cases (the authors' own calculation from the voting records of the General Assembly).

5. For example, as many as 137 states (including Georgia, Morocco, Russia, and Ukraine) provided exhaustive reports about the activities undertaken in order to implement the resolution.

6. EU-Russia Outreach Project website: http://www.excon.eu-rf.ru/en/?did=5_89 (acceded 14 December 2008).

7. 'Foreign Policy Strategy 2006-2009', $\quad$ pp. 9-10: http://www.mfa.gov.ge/files/115_1973_997704_Strategy_MFA2006-2009En.pdf (acceded 14 December 2008).

\section{References}

Allen, D. (1998) 'Who speaks for Europe?', in: J. Petersen and H. Sjursen (eds.): A Common Foreign Policy for Western Europe? Competing Visions of CFSP, London and New York: Routledge, pp. 41-58.

Association between the European Union and Morocco. The Association Council (2005) EU/Morocco Action Plan, UE-MA 2702/1/05, Brussels, 27 July 2005.

Balfour, R. (2004) Rethinking the Euro-Mediterranean political and security dialogue, Occasional Papers, 52, Paris: European Union Institute for Security Studies.

Barbé, E. (2008) 'Europeanisation, neighbourhood and European Foreign Policy’, in: K.Y Nikolov (ed.), Adapting to Integration in an Enlarged European Union, 
Volume 1: Adapting key policies in the Enlarged Union, Sofia: Bulgarian European Community Studies Association, pp. 148-173.

Bauer, M. W; Knill, Ch. and Pitschel, D. (2007) 'Differential Europeanization in Eastern Europe: The Impact of Diverse EU Regulatory Governance Patterns', Journal of European Integration 29(4): 405-424.

Benavides Orgaz, P. (2007) “El diálogo mediterráneo de la OTAN y la iniciativa de cooperación de Estambul”, in: E. Soler and L. Mestres (Eds.) V Seminario Internacional sobre Seguridad y Defensa en el Mediterráneo, Barcelona: Cidob Foundation, pp. 23-29.

Bicchi, F. (2006) '’Our Size fits all’: normative power Europe and the Mediterranean', Journal of European Public Policy 13(2): 286-303.

Björkdahl, A. (2005) 'Norm-maker and Norm-taker: Exploring the Normative Influence of the EU in Macedonia', European Foreign Affairs Review 10(2): 257-278.

Boguslawska, H. (2008) La politique européenne de sécurité et de défense: le dialogue entre l'UE et ses partenaires méditerranées, Rabat, 14 mars, Paris: European Union Institute for Security Studies.

Bulmer, S. J. and Radaelli, C.M. (2004) 'The Europeanisation of National Policy?', Queen's Papers on Europeanisation, 1/2004, Belfast: Queen’s University.

Checheyuk, L. (2008), 'Single Control List - Panacea Or A Step Backwards?’, Export Control Newsletter 1: 7-12.

Commission for the European Communities (2004) European Neighbourhood Policy Strategy Paper, COM(2004) 373 final, Brussels, 12 May 2004.

Commission for the European Communities (2008) Rapport de Suivi Maroc, SEC(2008) 398, Brussels, 3 April 2008. 
Council of the European Union (2000a) “Council Regulation (EC) No 1334/2000 of 22 June 2000 setting up a Community regime for the control of exports of dual-use items and technology”, Official Journal of the European Communities, L 159, 30 June 2000.

Council of the European Union (2000b) Relations with Ukraine - Establishment of the position of the European Union for the third meeting of the Cooperation Committee with Ukraine (Brussels, 18 December 2000), 14479/00, Brussels, 12 December 2000.

Council of the European Union (2001), Relations with Ukraine - Council report to the European Council on the implementation of the Common Strategy of the European Union on Ukraine, 15195/01, Brussels, 11 December 2001.

Council of the European Union (2003) Fight against the proliferation of weapons of mass destruction - EU strategy against proliferation of Weapons of Mass Destruction, 15708/03, Brussels, 10 December 2003.

Council of the European Union (2005a) 15th EU-Russia Summit, Moscow, 10 May 2005, Road Maps, 8799/05 ADD 1 (Presse 110), Brussels, 11 May 2005.

Council of the European Union (2005b) Implementation of the EU Training Concept in ESDP, 7774/05, Brussels, 5 April 2005.

Council of the European Union (2006) Implementation of the recommendations of the Peer Review of Member States' export control systems for dual use goods - Report on progress made in 2006 noted by Council on 11 December 2006, 16507/06, Brussels, 12 December 2006.

EU-Morocco Association Council (2008) Document conjoint UE-Maroc sur le renforcement des relations bilatérales/ Statut Avancé, 13653/08, Brussels, 13 October 2008. 
Gomart, Th. (2008) EU-Russia Relations. Towards a Way out of Depression, Washington/Paris: CSIS/IFRI.

Kelley, J. (2006) 'New Wine in Old Wineskins: Promoting Political Reforms through the New European Neighbourhood Policy', Journal of Common Market Studies 44(1): 29-55.

Kirchner, E. J. (2006) 'The Challenge of European Union Security Governance', Journal of Common Market Studies 44(5): 947-968.

Knill, Ch. (2005) 'Introduction: Cross-national policy convergence: concepts, approaches and explanatory factors', Journal of European Public Policy 12(5): 764-774.

Lavenex, S. and Schimmelfennig, F. (2009) 'EU rules beyond EU borders: theorizing external governance in European politics', Journal of European Public Policy, forthcoming.

Lavenex, S. (2004) 'EU external governance in 'wider Europe’', Journal of European Public Policy 11(4): 680-700.

Lavenex, S. and Uçarer, E. M. (2004) 'The External Dimension of Europeanization', Cooperation and Conflict 39(4): 417-443.

Lavenex, S., Lehmkuhl, D. and Wichmann, N. (2008) 'Die Nachbarschaftspolitiken der Europäischen Union: zwischen Hegemonie und erweiterter Governance', in: T. Ingeborg (ed.), Die Europäische Union. Governance und Policy-Making, Wiesbaden: VS, Verl. für Sozialwissenschaften pp. 367-388.

Matiussi, J. (2007) 'Developing EU Co-operation with third Countries in the Export Control of Dual Use Goods and Technologies', Eighth Annual International Export Control Conference, 6-8 March, Bucharest, Romania. 
Müller-Brandeck-Bocquet, G. (2002) 'The New CFSP and ESDP Decision-Making System of the European Union', European Foreign Affairs Review, 7(2): 257-282. Partnership between the European Union and Georgia. The Co-operation Council (2006) EU/Georgia Action Plan, UE-GE 4654/06, Brussels, 8 November 2006.

Partnership between the European Union and Ukraine. The Co-operation Council (2005) EU/Ukraine Action Plan, UE-UA 1051/05, Brussels, 14 February 2005.

Prodi, R. (2002) ‘A Wider Europe - A Proximity Policy as the key to stability’, Speech to the Peace, Security and Stability International Dialogue and the Role of the EU, Sixth ECSA-World Conference. Brussels, 5 - 6 December.

Sari, A. (2008) 'The Conclusion of International Agreements by the European Union in the Context of the ESDP', International and Comparative Law Quarterly 57(1): 5386.

Schmitt, B. (2001) 'A Common European Export Policy for Defence and Dual-use Items?’, Occasional Papers, 25, Paris: Institute for Security Studies.

Scientific and Technical Center (2008), Report 'Improvement of the normative and legislative basis of Ukraine in the field of export control and its harmonization with the European Union Standards, Kiev.

Smith, M. E. (2004) 'Toward a theory of EU foreign policy-making: multi-level governance, domestic politics, and national adaptation to Europe’s common foreign and security policy’, Journal of European Public Policy 11(4): 740-758.

Smith, M. E. and Webber, M. (2007) 'Political dialogue and security: the CFSP and ESDP', in: K. Weber, M. E. Smith and M. Baun (eds.) Governing Europe's neighbourhood. Partners or periphery?, Manchester and New York: Manchester University Press, pp. 58-75. 
Splidsboel-Hansen, F. (2002) 'Explaining Russian Endorsement of the CFSP and the ESDP', Cooperation and Conflict 33(4): 443-456.

Stetter, S. (2007) EU Foreign and Interior Policies: Cross-Pillar Politics and the Social Construction of Sovereignty, London and New York: Routledge.

The Georgian Times (2007), 'Georgia Moves Closer to the EU by Aligning with it on International Arena', 11 June.

Webber, M. (2001) 'Third-Party Inclusion in European Security and Defence Policy: A Case Study of Russia’, European Foreign Affairs Review 6(4): 407-426. 